\title{
Review \\ Regulation of mammary gland branching morphogenesis by the extracellular matrix and its remodeling enzymes
}

\author{
Jimmie E Fata ${ }^{1}$, Zena Werb ${ }^{2}$ and Mina J Bissell ${ }^{1}$ \\ ${ }^{1}$ Life Sciences Division, Lawrence Berkeley National Laboratory, Berkeley, CA, USA \\ 2Department of Anatomy, University of California, San Francisco CA, USA \\ Corresponding authors: Mina J Bissell (e-mail: mjbissell@lbl.gov) and Jimmie E Fata (e-mail: jefata@lbl.gov)
}

Published: 19 August 2003

Breast Cancer Res 2004, 6:1-11 (DOI 10.1186/bcr634)

(c) 2004 BioMed Central Ltd (Print ISSN 1465-5411; Online ISSN 1465-542X)

\begin{abstract}
A considerable body of research indicates that mammary gland branching morphogenesis is dependent, in part, on the extracellular matrix (ECM), ECM-receptors, such as integrins and other ECM receptors, and ECM-degrading enzymes, including matrix metalloproteinases (MMPs) and their inhibitors, tissue inhibitors of metalloproteinases (TIMPS). There is some evidence that these ECM cues affect one or more of the following processes: cell survival, polarity, proliferation, differentiation, adhesion, and migration. Both three-dimensional culture models and genetic manipulations of the mouse mammary gland have been used to study the signaling pathways that affect these processes. However, the precise mechanisms of ECM-directed mammary morphogenesis are not well understood. Mammary morphogenesis involves epithelial 'invasion' of adipose tissue, a process akin to invasion by breast cancer cells, although the former is a highly regulated developmental process. How these morphogenic pathways are integrated in the normal gland and how they become dysregulated and subverted in the progression of breast cancer also remain largely unanswered questions.
\end{abstract}

Keywords: branching morphogenesis; extracellular matrix (ECM); integrins; mammary gland; matrix metalloproteinases (MMPs)/tissue inhibitors of MMPs (TIMPs)

\section{Introduction}

Relatively simple in its form and function, the mammary gland nevertheless requires a complex interplay of both intracellular and extracellular signals for its development into a branched glandular structure. The extracellular matrix (ECM) has long been recognized as providing morphogenic signals during mammary gland branching morphogenesis [1]. However, systematic studies to define the precise mechanism(s) by which the ECM accomplishes its role are lacking. The unanswered questions include: do interstitial ECM and basement membrane (BM) act as single entities or do their individual components have distinct effects? What ECM receptors are used to transmit these signals, and how do ECM remodeling proteinases fit into these morphogenic events? In this review, we briefly summarize a vast amount of research that touches on these areas. We mention several existing hypotheses, put forth a few more, and suggest some possible future directions for the field.

A branched epithelial structure includes a network of tubes that are integral to the function of a number of glandular organs [2,3]. Lung [4], kidney [5], salivary gland $[6,7]$, and mammary gland $[8,9]$ are examples of organs that develop through branching morphogenesis. The latter is unique among these organs in that the majority of its branching is postembryonic. Extensive branching begins in puberty in the female and ceases after expanding to the outer limits of the mesenchymal fat pad. A number of paracrine, juxtacrine, and autocrine factors are known to affect mammary gland branching morphogenesis [10]. We have summarized these factors in Table 1 ; however, a detailed discussion of these factors is beyond the scope of this review. Here, we focus primarily on the studies that

$\mathrm{ADAM}=$ a disintegrin and metalloproteinase; $\mathrm{BM}=$ basement membrane; DDR1 = discoidin domain receptor $1 ; \mathrm{ECM}=$ extracellular matrix; EMT = epithelial-to-mesenchymal transition; MMPs = matrix metalloproteinases; TACE = tumor-necrosis-factor-a-converting enzyme; TIMP = tissue inhibitor of metalloproteinase; UPA = urokinase plasminogen activator. 
Table 1

\begin{tabular}{|c|c|c|c|}
\hline Morphogen & Branching* $^{*}$ & Mode of application & Reference \\
\hline \multicolumn{4}{|l|}{ Extracellular factors } \\
\hline Estrogen & $\uparrow$ & Administered & [110] \\
\hline Estrogen & $\uparrow$ & Slow-release pellet & [111] \\
\hline Anti-estrogen & $\downarrow$ & Slow-release pellet & [112] \\
\hline Progesterone & $\downarrow$ & Slow-release pellet & [113] \\
\hline Parathyroid-hormone-related peptide & $\downarrow$ & Homozygous deletion & {$[114]$} \\
\hline Parathyroid-hormone-related peptide & $\downarrow$ & Transgenic overexpression & [115] \\
\hline Parathyroid hormone & $\downarrow$ & Transgenic overexpression & [115] \\
\hline Corticosterone & $\downarrow$ & Administered & {$[116]$} \\
\hline Epidermal growth factor (EGF) & $\uparrow$ & Slow-release pellet & [117] \\
\hline TGF- $\beta 1$ & $\downarrow$ & Slow-release pellet & {$[118,119]$} \\
\hline TGF- $\beta 2$ & $\downarrow$ & Slow-release pellet & {$[118]$} \\
\hline TGF- $\beta 3$ & $\downarrow$ & Slow-release pellet & {$[118]$} \\
\hline Insulin-like growth factor 1 & $\downarrow$ & Homozygous deletion & [120] \\
\hline Growth hormone & $\uparrow$ & Slow-release pellet & {$[117]$} \\
\hline Hepatocyte growth factor & $\uparrow$ & Transgenic overexpression & {$[121]$} \\
\hline Relaxin & $\uparrow$ & Systemically administered & [122] \\
\hline Amphiregulin & $\uparrow$ & Overexpressing transplants & {$[123]$} \\
\hline Amphiregulin & $\uparrow$ & Slow-release pellet & [123] \\
\hline Hereguln- $\alpha$ & $\uparrow$ & Slow-release pellet & [124] \\
\hline Heregulin- $\beta$ & $\uparrow$ & Slow-release pellet & {$[124]$} \\
\hline Wnt-4 & $\downarrow$ & Homozygous deletion & [125] \\
\hline Wnt-4 & $\uparrow$ & Overexpressing transplants & {$[126]$} \\
\hline C-neu & $\downarrow$ & Transgenic overexpression & {$[127]$} \\
\hline Colony-stimulating factor & $\downarrow$ & Homozygous deletion & [128] \\
\hline Eotaxin & $\downarrow$ & Homozygous deletion & {$[128]$} \\
\hline MMP-3 (stromelysin-1) & $\uparrow$ & Transgenic overexpression & {$[69,70]$} \\
\hline TIMP-1 & $\uparrow$ & Transgenic antisense TIMP-1 & [12] \\
\hline TIMP-1 & $\downarrow$ & Slow-release pellet & {$[12]$} \\
\hline \multicolumn{4}{|l|}{ Receptors } \\
\hline EGF receptor (EGFR) & $\downarrow$ & Homozygous deletion & [129] \\
\hline Epidermal-growth-factor receptor & $\uparrow$ & Transgenic/dominant negative & [130] \\
\hline Estrogen receptor $\alpha$ & $\downarrow$ & Homozygous deletion & {$[131]$} \\
\hline Progesterone receptor A (PRA) & $\uparrow$ & Transgenic overexpression & [132] \\
\hline Progresterone receptor A/B & $\downarrow$ & Homozygous deletion & [133] \\
\hline Prolactin receptor & $\downarrow$ & Homozygous deletion & [134] \\
\hline TGF- $\beta 2$ receptor & $\uparrow$ & Transgenic/dominant negative & {$[135]$} \\
\hline \multicolumn{4}{|l|}{ Intracellular factors } \\
\hline CCAAT/enhancer binding protein $\beta$ & $\downarrow$ & Homozygous deletion & {$[136,137]$} \\
\hline Gelsolin & $\downarrow$ & Homozygous deletion & {$[138]$} \\
\hline Hox6C & $\downarrow$ & Homozygous deletion & [139] \\
\hline
\end{tabular}

$\star \uparrow$, augmentation of branching; $\downarrow$, inhibition of branching. MMP, matrix metalloproteinase; TGF, transforming growth factor; TIMP, tissue inhibitor of metalloproteinase. 
involve ECM, integrin and nonintegrin ECM receptors, ECM-degrading proteinases, and proteinase inhibitors in regulation of mouse mammary gland branching morphogenesis.

Branched structures are first seen in the mouse mammary gland in late embryonic development [11]. Expansion of the ductal tree within the fat pad occurs rapidly after 3 to 4 weeks of age, when ovarian hormones begin systemic circulation, and ceases around 10 weeks of age [12]. During branching morphogenesis, primary ducts elongate, driven by terminal end bud proliferation, and the tree 'fans out' within the fat pad through a process of terminal end bud bifurcation and lateral side branching. Given the complexity of mammary gland morphogenesis, we recommend that models used to study this process consider the following three criteria: the length of the duct [ductal extension], the bifurcation of leading or primary ducts [or a measure of the number of primary ducts], and the number of side branches formed independently of bifurcation [lateral branching from existing ducts]. These distinctions are necessary, because there is some evidence to indicate that each of these processes is differentially regulated by ECM molecules, ECM receptors, the ECM degrading/ inhibiting enzymes, and soluble branching morphogens. After 10 weeks of age, alveolar differentiation/regression is the predominant morphological event, under the influence of the estrous cycle [13-15]. During pregnancy, more lateral branching occurs to provide a connection between milk-producing alveoli and primary collecting ducts [16]. In most aspects, human breast development resembles mouse mammary gland development [17], although there are some notable differences [18].

Mammary ducts consist of an epithelial layer intimately associated with a single layer of myoepithelial cells at their basal end. A sheath of BM encircles the duct, which in turn is surrounded by an outer ring of fibrous interstitial ECM surrounded by a loose connective tissue. Within the ductal unit, myoepithelial cells are more intimately connected to BM than are epithelial cells, a spatial arrangement that changes during different stages of mammary development and cancer $[19,20]$. During morphogenesis of the gland, differences in the composition, size, and most probably function of the BM can be found when comparing terminal end buds to subtending ducts. For instance, the BM of terminal end buds displays differences in thickness, being thinner $(104 \mathrm{~nm})$ at the tip and becoming extensively thicker $(1.4 \mu \mathrm{m})$ along the flank of the terminal end bud. Moreover, the BM at the tip of the terminal end bud is rich in hyaluronic acid, which may mediate morphogenesis [21]. The BM of the ducts, in contrast, is a meshwork of collagen type IV, laminin 1, laminin 5, and heparan sulfate proteoglycans; other constituents such as entactin/nidogen, vitronectin, and fibronectin are also present [22].
Early studies involving development of the mammary gland in vivo showed that inhibition or augmentation of either collagens or glycosaminoglycan deposition attenuates branching $[1,21,23]$. These experiments indicated that regulation of mammary gland branching morphogenesis in vivo is dependent not only on the maintenance of specific types of ECM but also on total amounts of ECM. Therefore, the regulation of branching may be dictated by the composition of the ECM components present, the quantity of the components, and where they are situated within the developing tree. For instance, growth-promoting, nonadhesive, and promigratory ECM components may be more prominent at the front of terminal end buds, whereas ECM with the opposite characteristics could be found around stationary ducts (Fig. 1). However, this hypothesis may be too simplistic, because several ECM components exhibit both promoting and inhibitory characteristics, depending on the model used or the cell line examined [22], and, as we discuss later, ECM receptors and ECM-degrading proteinases need to be integrated into any mechanism of ECM-directed morphogenesis.

\section{ECM-receptor control of branching morphogenesis}

Direct attachment of epithelial cells to ECM occurs through basally located integrins [24,25] (Table 2) and nonintegrin ECM receptors [26-29] (Table 3). Gene knockout studies in mice where particular integrin subunit has been deleted indicate that integrin heterodimers containing $\alpha 3, \alpha 6$, or $\beta 4$ integrin subunits are not required for mammary branching morphogenesis [30], while $\alpha 2$ integrin knockouts exhibit diminished branching [31]. In cultures of human mammary epithelial cells, blocking antibodies against $\alpha_{3}$ integrin enhance branching when cells are cultured within collagen type I [32], while the same antibody inhibits branching when cells are cultured on top of laminin rich basement membrane gel (IrBM), Matrigel (BD Biosciences, Bedford, MA) [33]. These two studies indicate that one integrin may relay opposing morphogenic signals depending on which ECM ligand is present, and that branching assays in culture may not coincide with in vivo findings. The $\alpha_{6} \beta_{4}$ integrin, which is expressed in myoepithelium in vivo and in most immortalized breast cell lines, is another integrin that is necessary for branching in culture [33] but not in vivo [34]. Several studies have examined the function of $\beta_{1}$ integrin during mammary gland branching morphogenesis. In vivo, developing mammary glands confronting blocking antibodies against the $\gamma_{1}$ chain of laminin (a subunit of all laminins except laminin 5 and a major ligand of $\beta_{1}$ integrin subunit) or function-perturbing $\beta_{1}$ integrin antibodies show terminal end bud regression, fewer terminal end buds, and decreased ductal elongation, while blocking antibodies against the $\alpha_{6}$ integrin subunit had no effect [35]. In contrast, transgenic mice expressing a dominant negative $\beta_{1}$ integrin subunit under the control of the MMTV (mouse 


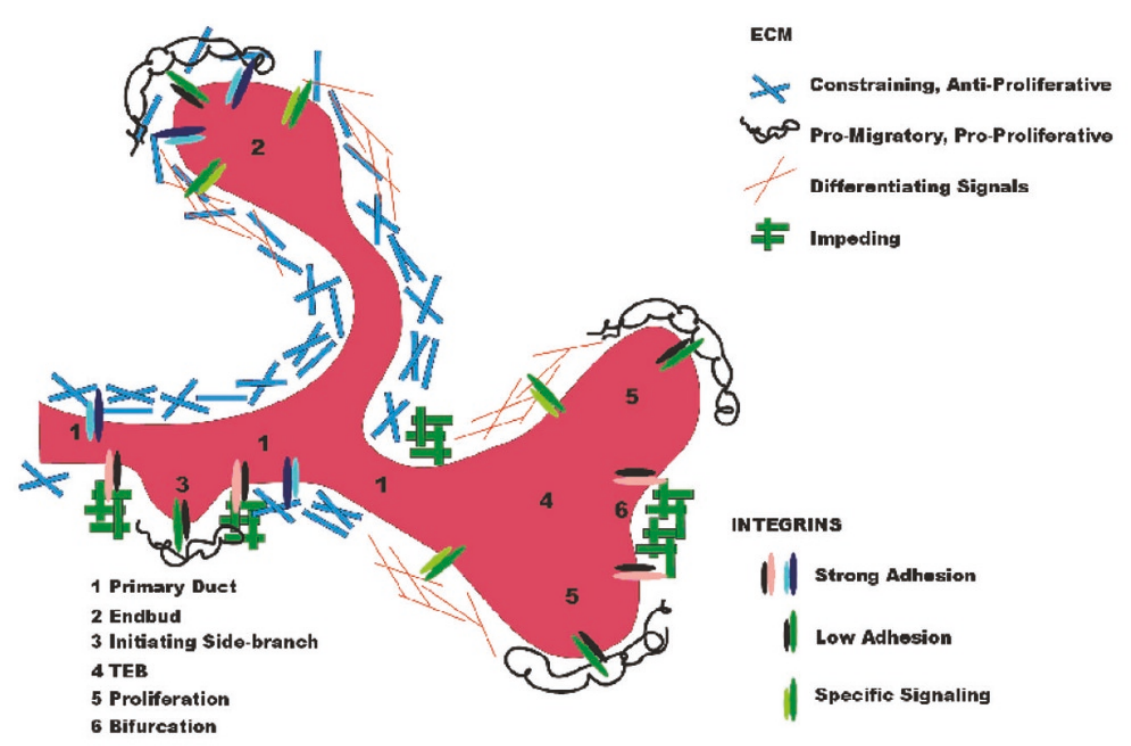

Proposed spatial organization of the extracellular matrix (ECM) and integrin function during mammary gland branching morphogenesis. The composition of the ECM that surrounds developing ducts and the type of integrin that relays signals from the ECM would depend on the morphogenic event. Areas requiring invasion and proliferation and low adhesion (TEBs [terminal end buds], side branching) would have a unique ECM/integrin profile compared with areas that are dormant (primary ducts, noninvasive end buds). Unique signals in areas that may require stem or progenitor cell differentiation may require specific ECM-integrin profiles, unlike other areas.

mammary tumor virus) promoter do not exhibit altered mammary gland branching morphogenesis, but instead showed a reduction in alveolar differentiation and an increase in alveolar apoptosis [35]. In cultures of collagen type I, blocking $\beta_{1}$ integrin function inhibits branching, as does blocking $\alpha_{2}$ integrin function [32]. These conflicting $\beta_{1}$ integrin results may stem from differences in the nature of the cell types or ECM that confront the $\beta_{1}$ integrin antibody and the extent of its loss or overexpression. In vivo, endogenous $\beta_{1}$ integrin is found in several cell types, including the cap cells of terminal end buds, myoepithelial cells, and luminal epithelial cells [35]. To make the picture even more confusing, conditional knockout of $\beta_{1}$ integrin, within the mammary gland, appears to have no obvious phenotypic consequences for the development of the mammary gland (William Muller, McGill University, personal communication). Integrin studies have indicated that for normal ductal development to occur, ECM adherence through specific integrin subunits is necessary; however, de-adherence is also required for normal branching, since antibodies against $\beta_{1}$ integrin, which 'anchors' cells to ECM, attenuate branching morphogenesis [36]. Factors that determine integrin-binding characteristics are complex and include subunit composition, integrin recognition sequences within the ligands, the nature of the divalent cation present, and the activation state (high anchoring or low) of the integrin [37]. Finally, spatial distribution of integrins within the developing ductal tree must explored. It is likely that integrins, in a manner analogous to the ECM components, are differentially localized or differentially activated within a developing tree, where promorphogenic integrins are found in areas of migration, invasion, and de-adhesion and integrins with opposite characteristics are found at the base of the branching point or at the cleft of a bifurcating structure (see Fig. 1).

Nonintegrin ECM receptors have also been implicated in mammary gland branching morphogenesis. Overexpressing cell-surface $\beta$-1,4-glactosyltransferase (GalTase) in mammary epithelium leads to inhibition of mammary gland morphogenesis [38]. This receptor participates in both cell-cell and cell-ECM interactions through recognition of $\mathrm{N}$-acetylglucosamine residues on glycosylated ligands. It is likely that dystroglycan, another nonintegrin cell-surface ECM receptor, plays a key role in mediating morphogenic signals from laminin 1 for acinus formation in the mammary gland [39]; it may also be involved in branching signals, as is the case in lung, kidney, and salivary glands [40]. Several types of collagen can act as ligands capable of activating the discoidin domain receptor 1 (DDR1) tyrosine kinase [41]. DDR1 is expressed on both epithelium and myoepithelium, and DDR1-deficient mice have excessive mammary collagen deposition, delayed ductal development, enlarged terminal end buds, hyperproliferative ducts, and incomplete lactational differentiation [42]. Galectin, another nonintegrin ECM receptor, may also function during mammary gland branching morphogene- 
Table 2

\begin{tabular}{ll} 
Integrin heterodimers and their corresponding ECM ligands \\
\hline Integrin & ECM ligands \\
\hline$\alpha_{1} \beta_{1}$ & Laminins, collagens \\
$\alpha_{2} \beta_{1}$ & Laminins, collagens, tenascin \\
$\alpha_{3} \beta_{1}$ & Laminins, collagens, fibronectin, entactin \\
$\alpha_{4} \beta_{1}$ & Fibronectin, osteopontin \\
$\alpha_{5} \beta_{1}$ & Fibronectin, tenascin \\
$\alpha_{6} \beta_{1}$ & Laminins \\
$\alpha_{7} \beta_{1}$ & Laminins \\
$\alpha_{8} \beta_{1}$ & Fibronectin, tenascin, vitronectin \\
$\alpha_{9} \beta_{1}$ & Collagen type I, laminin, tenascin, osteopontin \\
$\alpha_{\mathrm{V}} \beta_{1}$ & Vitronectin, fibronectin, osteopontin \\
$\alpha_{2} \beta_{1}$ & Collagen type I \\
$\alpha_{11 b} \beta_{3}$ & Fibronectin, vitronectin, thrombospondin \\
$\alpha_{\mathrm{V}} \beta_{3}$ & Vitronectin, fibronectin, osteopontin, entactin, \\
$\alpha_{6} \beta_{4}$ & thrombospondin, denatured collagens, tenascin, laminin \\
$\alpha_{\mathrm{V}} \beta_{5}$ & Laminins \\
$\alpha_{\mathrm{V}} \beta_{6}$ & Fitronectin, osteopontin, fibronectin \\
$\alpha_{\mathrm{V}} \beta_{7}$ & Fibronectin \\
$\alpha_{\mathrm{V}} \beta_{8}$ & Fibronectin, vitronectin \\
\hline$A_{2}$ &
\end{tabular}

Adapted from [140].

sis, since it has been shown to regulate ureteric bud branching in the kidney [43].

\section{Relation between ECM-degrading proteinase activity and branching morphogenesis}

Pioneering experiments from the Wessels and Bernfield laboratories showed that increased activity of ECMdegrading proteinases, such as collagenase or hyaluronidase, altered branching morphogenesis in kidney, lung, salivary gland, and pancreas [44,45]. Subsequent studies found that collagenase reduced bifurcation by inhibiting the deposition of collagen type I fibrils in the developing salivary gland [46], and that a collagenase inhibitor increased bifurcation, presumably by increased deposition of collagen type 1 fibrils at the cleft. However, ECM-degrading proteinases could affect branching morphogenesis at levels well beyond the physical consequences of remodeling the ECM (Fig. 2). First, signaling through cell-ECM receptors would be lost or modified when ECM is altered through ECM-degrading proteinase activity $[47,48]$. Second, neo-epitopes, cryptic in intact ECM molecules, may be exposed after digestion of ECM, to provide new morphogenic signals to surrounding cells $[49,50]$. Third, factors capable of influencing morphogenesis, which are intimately sequestered by ECM, may now
Table 3

Nonintegrins implicated in branching morphogenesis

Nonintegrin ECM ligands

\begin{tabular}{ll}
$\beta$-1,4-glactosyltransferase & $N$-acetylglucosamine residues \\
Dystroglycan & Laminin 1 \\
$\begin{array}{l}\text { Discoidin domain receptor } 1 \\
\text { (DDR1) }\end{array}$ & Collagens \\
Galectin & $\begin{array}{r}\text { Laminin, fibronectin, vitronectin, } \\
N \text {-acetylglucosamine residues }\end{array}$ \\
\hline
\end{tabular}

be released after ECM remodeling [51-54]. Fourth, cell-cell attachment molecules may be lost through proteolytic cleavage, thereby releasing cells for migration [55-57] or mesenchymal transition [57]. Finally, shedding of cell-surface receptors or bound factors by sheddases, which are also capable of digesting ECM, may release morphogens $[58,59]$.

Branching morphogenesis, whether examined in the mammary gland or in cell culture, involves an invasive process. One class of ECM-degrading proteinases is the matrix metalloproteinases (MMPs), many of which are capable of facilitating cellular invasion [60-62]. Their activity has been shown to mediate lung [63-65], kidney [34,66], and salivary gland [67] branching. In the mouse mammary gland, MMP mRNA and activity are evident during branching morphogenesis and involution [12,68-70]; and in transgenic mice, overexpression of active MMP 3, MMP 7 (matrilysin), and MMP 14 (MT1-MMP; membrane type-1MMP) led to ductal hyperplasia and in the case of MMP 3 and MMP 14 also to tumorigenesis [69,70-73]. Although limited branching analysis was performed in the MMP 7 and MMP 14 transgenic mice, these studies suggest that MMP 3 overexpression is associated with altered branching morphogenesis, while overexpression of MMP 7 or MMP 14 is not. Determining the differences in substrate specificities between MMPs should allow an understanding of why certain MMPs, when overexpressed, exhibit morphogenic capabilities while others do not. MMP 14 and MMP 2 are key proteinases in branching morphogenesis during epidermal-growth-factor-mediated lung development [74], and MMP 14, independent of pro-MMP 2 activation, can confer invasion and tubulogenesis of noninvasive MDCK cells in matrices of collagen type I, while MMPs $1,2,3,7,9,11$, and 13 cannot [75]. Therefore, tissue specificity also appears to determine whether specific MMPs can act as branching morphogens.

Induction of MMP 3 in a clonal mouse mammary epithelial cell line, ScP2 [76], leads to cleavage of E-cadherin, loss of associated $\beta$-catenin, and epithelial-to-mesenchymal transition (EMT), and to an invasive phenotype [57]. We 


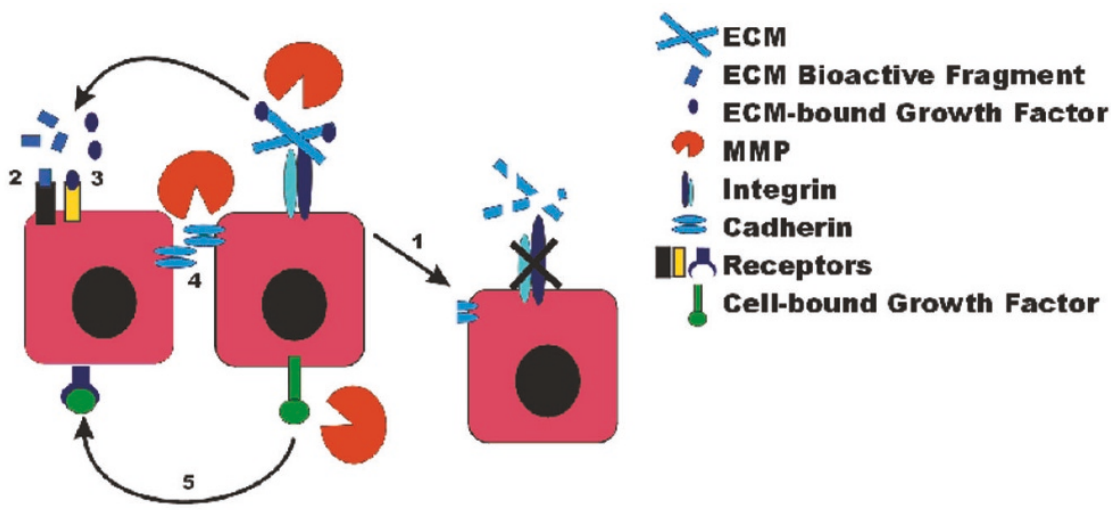

1. Loss of ECM-receptor interactions

2. Generation of bioactive ECM fragments

3. Release of ECM-sequestered factors

4. Loss of cell-cell adherence

5. Shedding of ligands or receptors

Mechanism by which matrix metalloproteinases (MMPs) can affect branching morphogenesis. 1. Proteolytic digestion of extracellular matrix (ECM) would alter ECM-integrin tethering and ECM-integrin signalling $[47,48]$. 2. Cleavage of ECM may produce soluble ECM fragments containing morphogenic activity $[49,50,53,54]$. 3. ECM-sequestered factors may be released to produce morphogenic gradients or signalling [52,54]. 4. Loss of cell-cell adhesion molecules by MMPs would lead to epithelial-to-mesenchymal transition and increased invasiveness [55-57]. 5. Ligand or receptor shedding might initiate autocrine, juxtacrine, or paracrine morphogenic signalling $[58,59]$.

have further shown that MMP 3 can induce branching morphogenesis in mammary organoids in three-dimensional cultures of collagen type I [77]. Importantly, MMP 3induced branching occurs in the absence of added growth factors in these organoid cultures. It is tempting to speculate that MMP 3 activity leads to a transient EMT that may be necessary for the invasion of the mammary gland ductal tree in the fat pad (Fig. 3). The idea is that at the leading edge of ductal migration, epithelial cells may exhibit mesenchymal-like characteristics allowing them to invade as an organized structure, similar to what happens in the development and patterning of several other tissues and organs that exhibit EMT [78].

We have determined that the minimal requirements for branching morphogenesis in clonal populations of mammary epithelial cells are MMP 3 plus epimorphin, a myoepithelial- and stromal-derived mammary morphogen [79]. Indeed, epithelial cells that branch in culture without requiring additional exogenous epimorphin are those that already express epimorphin [80]. Increased expression of epimorphin in mammary glands of transgenic mice leads to enlarged ducts and increased alveoli, underscoring its role in mammary gland morphogenesis [80]. We have found that epimorphin-mediated branching occurs in part through upregulation of MMPs, including MMP 3 [77]. These culture studies, along with the transgenic work cited above, provide a role for MMP 3 and epimorphin as two key morphogenic factors during mammary gland branching morphogenesis.
The serine proteinases urokinase plasminogen activator (UPA) and tissue plasminogen activator process plasminogen into plasmin, which, in turn, is capable of degrading ECM and activating MMPs [81]. Plasminogen, but not UPA, has been shown to be necessary for normal mammary development, as plasminogen-deficient mice show a delay in early ductal development and a large percentage of them are unable to lactate because of a lack of secretory epithelium [82]. In contrast, UPA-deficient mice show no detectable mammary phenotype during development or involution [82]. Other evidence suggests that the plasma kallikrein may be the dominant plasminogen activator in the mammary gland [83]. We have shown that MMPs can cooperate with the plasminogen/plasmin system during mammary epithelial branching morphogenesis in a three-dimensional matrix of collagen type l. These studies indicate that while UPA does not induce branching, plasmin can, but in an MMP-dependent manner [77]. In ongoing studies, a number of MMP-null mice are being examined during mammary gland branching morphogenesis to distinguish those MMPs mediating branching elongation versus those mediating lateral branching. These results suggest that certain MMPs, such as MMP 2, promote ductal elongation, whereas MMP 3 induces lateral side branching (Wiseman et al., JCB in press).

Determining the precise function of each ECM-degrading proteinase in branching morphogenesis is a time-consuming task, given their localization, activation, and interplay as well as their ever-increasing numbers. However, that pro- 
Figure 3

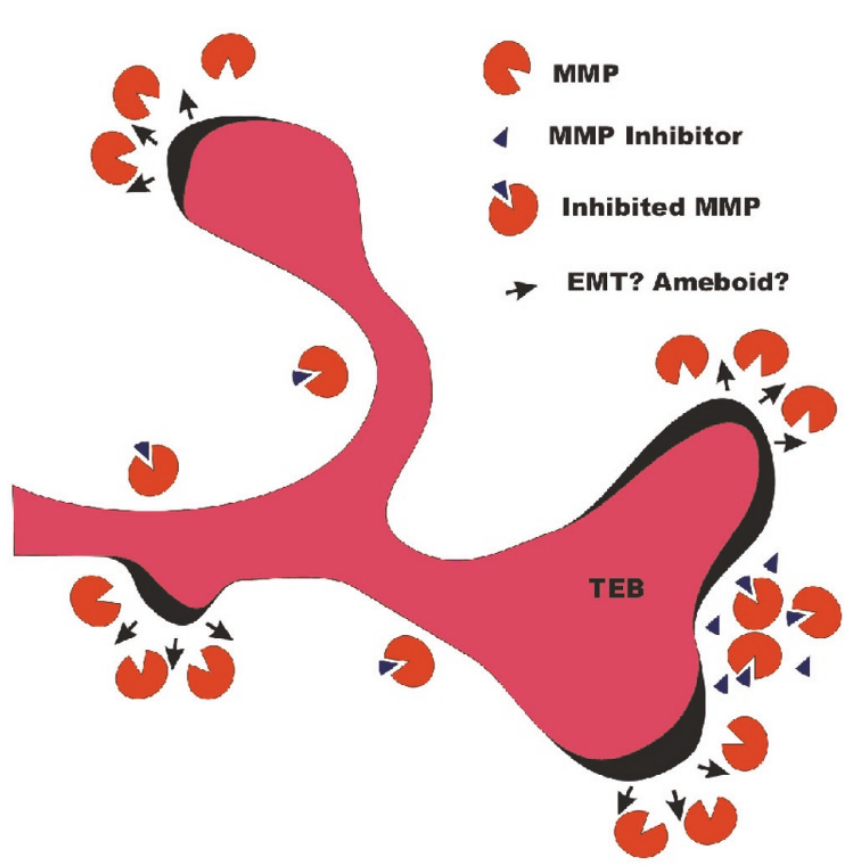

Proposed morphogenic mechanisms mediated by matrix metalloproteinases (MMPs) and MMP inhibitors. At sites of invasion and migration (TEBs [terminal end buds], lateral side branches, invasive end buds), MMP activity may induce a transient epithelial-tomesenchymal transition (EMT), thereby allowing the tip to move forward. Alternatively, high levels of MMP inhibitors may force an 'ameboid-like' movement, independent of MMP activity, through the meshwork of the extracellular matrix [96].

teinases do play a role in mammary branching is clear. There is more than one possible mechanism by which MMPs can regulate mammary gland branching morphogenesis (see Fig. 2); it will therefore be an interesting challenge to tease out which molecular pathway or pathways are involved for which proteinase during this developmental process. Focused research on the spatial distribution of substrates within the mammary gland and localization of MMP activities are likely to provide informative answers.

\section{MMP proteinase inhibitors in branching morphogenesis}

If ECM-degrading enzymes are involved in branching morphogenesis, one would then predict that their biological inhibitors should antagonize the process. While this is generally the case, the results are not always as predicted. For instance, upregulation of tissue inhibitor of metalloproteinase (TIMP)-1 increases bifurcation in the salivary gland [46] and induces higher numbers of branches in lung development [84], while in the mammary gland, upregulation of TIMP-1 leads to inhibition of ductal elongation without affecting bifurcation or higher-order branching [12]. In kidney development, TIMP-2 downregulation through antisense oligonucleotides increases ureteric branching morphogenesis [85], and, similarly, transgenic antisense expression of TIMP-1 leads to supernumerary branches associated with increased ductal elongation and increased mammary epithelial proliferation [12]. Therefore, the function of TIMPs, similar to that of MMPs, needs to be put in the context of tissue-specific microenvironments during branching morphogenesis [86]. It is likely that the processes of bifurcation and ductal extension, both characteristics of branching morphogenesis, are differentially regulated by TIMPs. That is, TIMP upregulation may increase bifurcation through increased focal deposition of ECM molecules, while concomitantly it may hinder ductal extension through limiting degradation of physically constraining ECM.

Downmodulation of TIMP-1 by transgenic antisense expression in the mammary gland leads to increased branching and is associated with a loss of laminin in the ductal BM but not collagen type IV, suggesting that laminin degradation may provide a morphogenic signal [12]. Cleavage of laminin 5 by MMP 2 (gelatinase A) and MMP 14 produces a laminin fragment capable of inducing mammary epithelial invasion $[50,87]$. However, whereas antisense downregulation of TIMP-1 augments branching morphogenesis, an analysis of TIMP-1-null mice indicates that mammary gland branching morphogenesis is not overtly affected (Fata and Khokha, unpublished findings, and Wiseman et al., JCB in press). It remains to be seen if compensatory upregulation of other TIMPs are occurring in these animals.

Given the multiplicity of MMP substrates, TIMPs should be viewed as molecules that mediate both ECM-dependent and ECM-independent events. TIMP-1 and TIMP-2 have been shown to stimulate growth of cells in culture, including breast cancer cells $[88,89]$. TIMP-2 mediates activation of MMP 2 on the cell surface through formation of a ternary complex with MMP 14 [90]. One could speculate that expression of TIMP-2 leads to an increase in the activation of MMP 2 on the cell surface by MMP 14, thereby localizing proteinase activity to the immediate extracellular space to augment branching. In MDCK cells, MMP 14 plays a pivotal role in invasion and branching morphogenesis in collagen-type-I matrix [91]. TIMP-3 has a unique ability to inhibit several cell-surface sheddases called ADAMs (a disintegrin and a metalloproteinase), including tumor-necrosis-factor- $\alpha$-converting enzyme (TACE; [92]), and so far is the only TIMP that becomes tightly bound to ECM after secretion [93]. TIMP-3-deficient mice show accelerated mammary involution and increased rates of adipogenesis [94]. The latter phenotype could be expected from evidence that indicates ADAMs contribute to adipogenesis [95]. Intriguingly, TACE-deficient mammary glands have a severe growth and branching phenotype (M Sternlicht, S Wohler Sunnarborg, DC Lee and $Z$ Werb, unpublished observation). It is possible that 
TIMPs could force mammary epithelial cells into an MMPindependent migration under some conditions (see Fig. 3). Recent results indicate that inhibition of metalloproteinases does not impede MDA-MB-231 mammary carcinoma cell migration through a collagen matrix, and the cells continue to move using an ameboid migration [96]. Whether or not this is a compensatory mechanism or whether these cells do not use MMPs at all remains to be determined.

\section{Conclusion: to branch or not to branch}

During expansion of the ductal tree into the fat pad, there is continuous turnover of both BM and stromal ECM $[12,21,97]$. We now know that this degradation is not only to remove an impediment to migration, but that it is also a process in which morphoregulatory signals are generated and/or quenched through remodeling. Remodeling and/or dissolution of impeding ECM would facilitate forward progression of a ductal branch and lessen adhesion of cells to their substrata. Improper remodeling of ECM in the mammary gland can lead to altered branching, as seen with hyaluronidase treatment [21], cis-hydroxyproline treatment [1], and changes in the proteinase/proteinase inhibitor balance $[12,69,70]$.

Understanding how ECM imparts morphoregulatory signals to breast epithelium is of importance also in carcinogenesis. Breast carcinoma most often is associated with an extensive 'stromal reaction' termed desmoplasia, in which excess collagen is deposited. In fact, changes in the integrity, deposition, and/or composition of the ECM are often associated with breast cancer $[22,98]$. Moreover, upregulation of expression of the fibrillar collagen gene is a robust indicator of metastatic phenotype [99-101]. ECM and factors that attenuate or augment signaling regulate branching morphogenesis in a process that may be thought of as controlled invasion. Where ECM accumulates aberrantly, as is the case for collagen type I in desmoplasia and fibrosis, other processes also begin to go wrong. For example, increased collagen type I has been shown to upregulate activated MMP 2 in human metastatic breast cancer cells [102]. This in turn could increase production of the morphogenic fragment of laminin 5, enhancing an already promigratory environment. Other collagens such as types III, V, and VII are also altered in expression and deposition in breast cancer [64,103-105], undoubtedly imparting signals that lead to loss of structure and function in the breast.

Laminin 1 has been shown to be produced by myoepithelial cells in the breast [20] and is downregulated in breast carcinoma together with the hemidesmosome integrin subunit $\alpha_{6}$ [106]. Downregulation of laminin 1 and $\alpha_{6}$ integrin is most likely due to the absence of the normal myoepithelial cells or the presence of aberrant breast cancer myoepithelial cells [20]. Other ECM proteins such cosaminoglycans also change in breast cancer [22]. Other hallmarks of breast cancer include altered expression of ECM-degrading proteinases and their inhibitors [107] as well as loss or aberrant expression of ECM receptors [108,109]. How different components of the cell-ECM signaling pathways contribute to the disease state is far from clear. What we do know is that proliferation, migration, and adhesion - all fundamental processes of morphogenesis - are profoundly affected.

\section{Competing interests}

None declared.

\section{Acknowledgements}

The work from the authors' laboratories is supported by the Director, Office of Biological and Environmental Research (contract DE-AC0376SF00098) of the US Department of Energy to MJB and by an 'Innovator' Award to MJB from the Department of Defense Breast Cancer Research Program (DAMD17-02-1-438) and by NIH grants CA64786 to MJB and CA57621 to ZW and MJB. JEF is supported by a California Breast Cancer Research Fellowship (\# 6FB-0131).

\section{References}

1. Wicha MS, Liotta LA, Vonderhaar BK, Kidwell WR: Effects of inhibition of basement membrane collagen deposition on rat mammary gland development. Dev Biol 1980, 80:253-256.

2. Gumbiner BM: Epithelial morphogenesis. Cell 1992, 69:385387.

3. Affolter M, Bellusci S, Itoh N, Shilo B, Thiery JP, Werb Z: Tube or not tube: remodeling epithelial tissues by branching morphogenesis. Dev Cell 2003, 4:11-18.

4. Hogan BL: Morphogenesis. Cell 1999, 96:225-233.

5. Horster MF, Braun GS, Huber SM: Embryonic renal epithelia: induction, nephrogenesis, and cell differentiation. Physiol Rev 1999, 79:1157-1191.

6. Morita K, Nogawa H: EGF-dependent lobule formation and FGF7-dependent stalk elongation in branching morphogenesis of mouse salivary epithelium in vitro. Dev Dyn 1999, 215: 148-154.

7. Fukuda $Y$, Masuda $Y$, Kishi J, Hashimoto $Y$, Hayakawa T, Nogawa $\mathrm{H}$, Nakanishi $Y$ : The role of interstitial collagens in cleft formation of mouse embryonic submandibular gland during initial branching. Development 1988, 103:259-267.

8. Daniel $\mathrm{CW}$, Smith GH: The mammary gland: a model for development. J Mammary Gland Biol Neoplasia 1999, 4:3-8.

9. Hennighausen L, Robinson GW: Signaling pathways in mammary gland development. Dev Cell 2001, 1:467-475.

10. Wiseman BS, Werb Z: Stromal effects on mammary gland development and breast cancer. Science 2002, 296:10461049.

11. Robinson GW, Karpf $A B$, Kratochwil K: Regulation of mammary gland development by tissue interaction. J Mammary Gland Biol Neoplasia 1999, 4:9-19.

12. Fata JE, Leco KJ, Moorehead RA, Martin DC, Khokha R: Timp-1 is important for epithelial proliferation and branching morphogenesis during mouse mammary development. Dev Biol 1999, 211:238-254.

13. Fata JE, Chaudhary V, Khokha R: Cellular turnover in the mammary gland is correlated with systemic levels of progesterone and not 17 beta-estradiol during the estrous cycle. Biol Reprod 2001, 65:680-688.

14. Andres AC, Strange R: Apoptosis in the estrous and menstrual cycles. J Mammary Gland Biol Neoplasia 1999, 4:221-228.

15. Ferguson JE, Schor AM, Howell A, Ferguson MW: Changes in the extracellular matrix of the normal human breast during the menstrual cycle. Cell Tissue Res 1992, 268:167-177.

16. Robinson GW, Hennighausen L, Johnson PF: Side-branching in the mammary gland: the progesterone-Wnt connection. Genes Dev 2000, 14:889-894.

17. Osborne MP: Breast Development and Anatomy. Philadelphia: Lippincott-Raven Publishers; 1996. 
18. Russo J, Russo IH: Development pattern of human breast and susceptibility to carcinogenesis. Eur J Cancer Prev 1993, 3:85100.

19. Emerman JT, Vogl AW: Cell size and shape changes in the myoepithelium of the mammary gland during differentiation. Anat Rec 1986, 216:405-415.

20. Gudjonsson T, Ronnov-Jessen L, Villadsen R, Rank F, Bissell MJ, Petersen OW: Normal and tumor-derived myoepithelial cells differ in their ability to interact with luminal breast epithelial cells for polarity and basement membrane deposition. $J$ Cell Sci 2002, 115:39-50.

21. Silberstein GB, Daniel CW: Glycosaminoglycans in the basal lamina and extracellular matrix of the developing mouse mammary duct. Dev Biol 1982, 90:215-222.

22. Lochter A, Bissell MJ: Involvement of extracellular matrix constituents in breast cancer. Semin Cancer Biol 1995, 6:165-173.

23. Silberstein GB, Strickland P, Coleman S, Daniel CW: Epithelium-dependent extracellular matrix synthesis in transforming growth factor-beta 1-growth-inhibited mouse mammary gland. J Cell Biol 1990, 110:2209-2219.

24. Alford D, Taylor-Papadimitriou J: Cell adhesion molecules in the normal and cancerous mammary gland. J Mammary Gland Biol Neoplasia 1996, 1:207-218.

25. Weaver VM, Petersen OW, Wang F, Larabell CA, Briand P, Damsky C, Bissell MJ: Reversion of the malignant phenotype of human breast cells in three-dimensional culture and in vivo by integrin blocking antibodies. J Cell Biol 1997, 137:231-245.

26. Elenius K, Salmivirta M, Inki P, Mali M, Jalkanen M: Binding of human syndecan to extracellular matrix proteins. $\mathrm{J} \mathrm{Biol} \mathrm{Chem}$ 1990, 265:17837-17843.

27. Barcellos-Hoff $\mathrm{MH}$ : Mammary epithelial reorganization on extracellular matrix is mediated by cell surface galactosyltransferase. Exp Cell Res 1992, 201:225-234.

28. Belkin AM, Smalheiser NR: Localization of cranin (dystroglycan) at sites of cell-matrix and cell-cell contact: recruitment to focal adhesions is dependent upon extracellular ligands. Cell Adhes Commun 1996, 4:281-296.

29. Warfield PR, Makker PN, Raz A, Ochieng J: Adhesion of human breast carcinoma to extracellular matrix proteins is modulated by galectin-3. Invasion Metastasis 1997, 17:101-112.

30. Klinowska TC, Alexander CM, Georges-Labouesse E, Van der NR, Kreidberg JA, Jones CJ, Sonnenberg A, Streuli CH: Epithelial development and differentiation in the mammary gland is not dependent on alpha 3 or alpha 6 integrin subunits. Dev Biol 2001, 233:449-467.

31. Chen J, Diacovo TG, Grenache DG, Santoro SA, Zutter MM: The alpha(2) integrin subunit-deficient mouse: a multifaceted phenotype including defects of branching morphogenesis and hemostasis. Am J Pathol 2002, 161:337-344.

32. Berdichevsky F, Alford D, D'Souza B, Taylor-Papadimitriou J: Branching morphogenesis of human mammary epithelial cells in collagen gels. J Cell Sci 1994, 107:3557-3568.

33. Stahl S, Weitzman S, Jones JC: The role of laminin-5 and its receptors in mammary epithelial cell branching morphogenesis. J Cell Sci 1997, 110:55-63.

34. Klinowska TC, Alexander CM, Georges-Labouesse E, Van der Neut R, Kreidberg JA, Jones CJ, Sonnenberg A, Streuli CH: Epithelial development and differentiation in the mammary gland is not dependent on alpha 3 or alpha 6 integrin subunits. Dev Bio/ 2001, 233:449-467.

35. Klinowska TC, Soriano JV, Edwards GM, Oliver JM, Valentijn AJ, Montesano $\mathrm{R}$, Streuli $\mathrm{CH}$ : Laminin and beta1 integrins are crucial for normal mammary gland development in the mouse. Dev Biol 1999, 215:13-32.

36. Alford D, Baeckstrom D, Geyp M, Pitha P, Taylor-Papadimitriou J: Integrin-matrix interactions affect the form of the structures developing from human mammary epithelial cells in collagen or fibrin gels. J Cell Sci 1998, 111:521-532.

37. Arnaout MA, Goodman SL, Xiong JP: Coming to grips with integrin binding to ligands. Curr Opin Cell Bio/ 2002, 14:641-651.

38. Hathaway HJ, Shur BD: Mammary gland morphogenesis is inhibited in transgenic mice that overexpress cell surface beta1,4-galactosyltransferase. Development 1996, 122:28592872.

39. Muschler J, Levy D, Boudreau R, Henry M, Campbell K, Bissell MJ: A role for dystroglycan in epithelial polarization: loss of function in breast tumor cells. Cancer Res 2002, 62:7102-7109.
40. Durbeej M, Ekblom P: Dystroglycan and laminins: glycoconjugates involved in branching epithelial morphogenesis. Exp Lung Res 1997, 23:109-118.

41. Vogel WF: Collagen-receptor signaling in health and disease. Eur J Dermatol 2001, 11:506-514.

42. Vogel WF, Aszodi A, Alves F, Pawson T: Discoidin domain receptor 1 tyrosine kinase has an essential role in mammary gland development. Mol Cell Bio/ 2001, 21:2906-2917.

43. Bullock SL, Johnson TM, Bao Q, Hughes RC, Winyard PJ, Woolf AS: Galectin-3 modulates ureteric bud branching in organ culture of the developing mouse kidney. J Am Soc Nephrol 2001, 12:515-523.

44. Wessells NK, Cohen JH: Effects of collagenase on developing epithelia in vitro: lung, ureteric bud, and pancreas. Dev Biol 1968, 18:294-309.

45. Banerjee SD, Cohn RH, Bernfield MR: Basal lamina of embryonic salivary epithelia. Production by the epithelium and role in maintaining lobular morphology. J Cell Biol 1977, 73:445-463.

46. Nakanishi $Y$, Sugiura F, Kishi J, Hayakawa T: Collagenase inhibitor stimulates cleft formation during early morphogenesis of mouse salivary gland. Dev Biol 1986, 113:201-206.

47. Stupack DG, Puente XS, Boutsaboualoy S, Storgard CM, Cheresh DA: Apoptosis of adherent cells by recruitment of caspase-8 to unligated integrins. J Cell Bio/ 2001, 155:459-470.

48. Rytomaa M, Lehmann $K$, Downward J: Matrix detachment induces caspase-dependent cytochrome $\mathrm{c}$ release from mitochondria: inhibition by PKB/Akt but not Raf signalling. Oncogene 2000, 19:4461-4468.

49. Felbor U, Dreier L, Bryant RA, Ploegh HL, Olsen BR, Mothes W: Secreted cathepsin $L$ generates endostatin from collagen XVIII. EMBO J 2000, 19:1187-1194.

50. Giannelli G, Falk-Marzillier J, Schiraldi O, Stetler-Stevenson WG, Quaranta V: Induction of cell migration by matrix metalloprotease-2 cleavage of laminin-5. Science 1997, 277:225-228.

51. Whitelock JM, Murdoch AD, lozzo RV, Underwood PA: The degradation of human endothelial cell-derived perlecan and release of bound basic fibroblast growth factor by stromelysin, collagenase, plasmin, and heparanases. J Biol Chem 1996, 271:10079-10086.

52. Bashkin P, Doctrow S, Klagsbrun M, Svahn CM, Folkman J, Vlodavsky I: Basic fibroblast growth factor binds to subendothelial extracellular matrix and is released by heparitinase and heparin-like molecules. Biochemistry 1989, 28:1737-1743.

53. Sinha S, Nevett C, Shuttleworth CA, Kielty CM: Cellular and extracellular biology of the latent transforming growth factorbeta binding proteins. Matrix Biol 1998, 17:529-545.

54. Quarto N, Amalric F: Heparan sulfate proteoglycans as transducers of FGF-2 signalling. J Cell Sci 1994, 107:3201-3212.

55. Ito K, Okamoto I, Araki N, Kawano Y, Nakao M, Fujiyama S, Tomita $\mathrm{K}$, Mimori T, Saya H: Calcium influx triggers the sequential proteolysis of extracellular and cytoplasmic domains of E-cadherin, leading to loss of beta-catenin from cell-cell contacts. Oncogene 1999, 18:7080-7090.

56. Noe V, Fingleton B, Jacobs K, Crawford HC, Vermeulen S, Steelant W, Bruyneel E, Matrisian LM, Mareel M: Release of an invasion promoter E-cadherin fragment by matrilysin and stromelysin-1. J Cell Sci 2001, 114:111-118.

57. Lochter A, Galosy S, Muschler J, Freedman N, Werb Z, Bissell MJ: Matrix metalloproteinase stromelysin-1 triggers a cascade of molecular alterations that leads to stable epithelial-to-mesenchymal conversion and a premalignant phenotype in mammary epithelial cells. J Cell Bio/ 1997, 139:1861-1872.

58. Schlondorff J, Blobel CP: Metalloprotease-disintegrins: modular proteins capable of promoting cell-cell interactions and triggering signals by protein-ectodomain shedding. $J$ Cell Sci 1999, 112:3603-3617.

59. Werb Z, Yan Y: A cellular striptease act. Science 1998, 282: 1279-1280.

60. Nelson AR, Fingleton B, Rothenberg ML, Matrisian LM: Matrix metalloproteinases: biologic activity and clinical implications. $J$ Clin Oncol 2000, 18:1135-1149.

61. Birkedal-Hansen $H$, Moore WG, Bodden MK, Windsor $L$, Birkedal-Hansen B, DeCarlo A, Engler JA: Matrix metalloproteinases: a review. Crit Rev Oral Biol Med 1993, 4:197-250.

62. Egeblad M, Werb Z: New functions for the matrix metalloproteinases in cancer progression. Nat Rev, Cancer 2002, 2:161174. 
63. Infeld MD: Cell-matrix interactions in gland development in the lung. Exp Lung Res 1997, 23:161-169.

64. Fukuda Y, Ishizaki M, Okada Y, Seiki M, Yamanaka N: Matrix metalloproteinases and tissue inhibitor of metalloproteinase-2 in fetal rabbit lung. Am J Physiol Lung Cell Mol Physiol 2000, 279: 555-561.

65. Baker SE, Hopkinson SB, Fitchmun M, Andreason GL, Frasier F, Plopper G, Quaranta V, Jones JC: Laminin-5 and hemidesmosomes: role of the alpha 3 chain subunit in hemidesmosome stability and assembly. J Cell Sci 1996, 109:2509-2520.

66. Lelongt B, Trugnan G, Murphy G, Ronco PM: Matrix metalloproteinases MMP2 and MMP9 are produced in early stages of kidney morphogenesis but only MMP9 is required for renal organogenesis in vitro. J Cell Biol 1997, 136:1363-1373.

67. Hayakawa T, Kishi J, Nakanishi Y: Salivary gland morphogenesis: possible involvement of collagenase. Matrix Supp/ 1992, 1: 344-351.

68. Talhouk RS, Chin JR, Unemori EN, Werb Z, Bissell MJ: Proteinases of the mammary gland: developmental regulation in vivo and vectorial secretion in culture. Development 1991, 112: 439-449.

69. Witty JP, Wright JH, Matrisian LM: Matrix metalloproteinases are expressed during ductal and alveolar mammary morphogenesis, and misregulation of stromelysin-1 in transgenic mice induces unscheduled alveolar development. Mol Biol Cell 1995, 6:1287-1303.

70. Sympson CJ, Talhouk RS, Alexander CM, Chin JR, Clift SM, Bissell MJ, Werb Z: Targeted expression of stromelysin-1 in mammary gland provides evidence for a role of proteinases in branching morphogenesis and the requirement for an intact basement membrane for tissue-specific gene expression. $J$ Cell Biol 1994, 125:681-693.

71. Sternlicht MD, Lochter A, Sympson CJ, Huey B, Rougier JP, Gray JW, Pinkel D, Bissell MJ, Werb Z: The stromal proteinase MMP3/stromelysin-1 promotes mammary carcinogenesis. Cell 1999, 98:137-146.

72. Ha HY, Moon HB, Nam MS, Lee JW, Ryoo ZY, Lee TH, Lee KK, So BJ, Sato H, Seiki M, Yu DY: Overexpression of membranetype matrix metalloproteinase-1 gene induces mammary gland abnormalities and adenocarcinoma in transgenic mice. Cancer Res 2001, 61:984-990.

73. Rudolph-Owen LA, Chan R, Muller WJ, Matrisian LM: The matrix metalloproteinase matrilysin influences early-stage mammary tumorigenesis. Cancer Res 1998, 58:5500-5506.

74. Kheradmand F, Rishi K, Werb Z: Signaling through the EGF receptor controls lung morphogenesis in part by regulating MT1-MMP-mediated activation of gelatinase A/MMP2. J Cell Sci 2002, 115:839-848.

75. Hotary K, Allen E, Punturieri A, Yana I, Weiss SJ: Regulation of cell invasion and morphogenesis in a three-dimensional type I collagen matrix by membrane-type matrix metalloproteinases 1, 2, and 3. J Cell Biol 2000, 149:1309-1323.

76. Desprez PY, Roskelley CD, Campisi J, Bissell MJ: Isolation of functional cell lines from a mouse mammary epithelial cell strain: the importance of basement membrane and cell-cell interactions. Mol Cell Diff 1993, 1:99-110.

77. Simian M, Hirai Y, Navre M, Werb Z, Lochter A, Bissell MJ: The interplay of matrix metalloproteinases, morphogens and growth factors is necessary for branching of mammary epithelial cells. Development 2001, 128:3117-3131.

78. Hay ED: An overview of epithelio-mesenchymal transformation. Acta Anat (Basel) 1995, 154:8-20.

79. Hirai Y, Lochter A, Galosy S, Koshida S, Niwa S, Bissell MJ: Epimorphin functions as a key morphoregulator for mammary epithelial cells. J Cell Biol 1998, 140:159-169.

80. Hirai $Y$, Radisky D, Boudreau R, Simian M, Stevens ME, Oka $Y$, Takebe K, Niwa S, Bissell MJ: Epimorphin mediates mammary luminal morphogenesis through control of C/EBPbeta. J Cell Biol 2001, 153:785-794.

81. Irigoyen JP, Munoz-Canoves P, Montero L, Koziczak M, Nagamine $Y$ : The plasminogen activator system: biology and regulation. Cell Mol Life Sci 1999, 56:104-132.

82. Lund LR, Bjorn SF, Sternlicht MD, Nielsen BS, Solberg H, Usher PA, Osterby R, Christensen IJ, Stephens RW, Bugge TH, Dano K, Werb Z: Lactational competence and involution of the mouse mammary gland require plasminogen. Development 2000, 127:4481-4492.
83. Selvarajan S, Lund LR, Takeuchi T, Craik CS, Werb Z: A plasma kallikrein-dependent plasminogen cascade required for adipocyte differentiation. Nat Cell Bio/ 2001, 3:267-275.

84. Ganser GL, Stricklin GP, Matrisian LM: EGF and TGF alpha influence in vitro lung development by the induction of matrixdegrading metalloproteinases. Int J Dev Biol 1991, 35:453-461.

85. Kanwar YS, Ota K, Yang Q, Wada J, Kashihara N, Tian Y, Wallner El: Role of membrane-type matrix metalloproteinase 1 (MT-1MMP), MMP-2, and its inhibitor in nephrogenesis. Am J Physiol 1999, 277:934-947.

86. $\mathrm{Vu} \mathrm{TH}, \mathrm{Werb} \mathrm{Z}$ : Matrix metalloproteinases: effectors of development and normal physiology. Genes Dev 2000, 14:21232133.

87. Koshikawa N, Giannelli G, Cirulli V, Miyazaki K, Quaranta V: Role of cell surface metalloprotease MT1-MMP in epithelial cell migration over laminin-5. J Cell Bio/ 2000, 148:615-624.

88. Hayakawa T, Yamashita K, Tanzawa K, Uchijima E, Iwata K: Growth-promoting activity of tissue inhibitor of metalloproteinases-1 (TIMP-1) for a wide range of cells. A possible new growth factor in serum. FEBS Lett 1992, 298:29-32.

89. Hayakawa T, Yamashita K, Ohuchi E, Shinagawa A: Cell growthpromoting activity of tissue inhibitor of metalloproteinases-2 (TIMP-2). J Cell Sci 1994, 107:2373-2379.

90. Ellerbroek SM, Stack MS: Membrane associated matrix metalloproteinases in metastasis. Bioessays 1999, 21:940-949.

91. Kadono Y, Shibahara K, Namiki M, Watanabe Y, Seiki M, Sato H: Membrane type 1-matrix metalloproteinase is involved in the formation of hepatocyte growth factor/scatter factor-induced branching tubules in madin-darby canine kidney epithelial cells. Biochem Biophys Res Commun 1998, 251:681-687.

92. Amour A, Slocombe PM, Webster A, Butler M, Knight CG, Smith BJ, Stephens PE, Shelley C, Hutton M, Knauper V, Docherty AJ, Murphy G: TNF-alpha converting enzyme (TACE) is inhibited by TIMP-3. FEBS Lett 1998, 435:39-44.

93. Yu WH, Yu S, Meng Q, Brew K, Woessner JF Jr.: TIMP-3 binds to sulfated glycosaminoglycans of the extracellular matrix. $J$ Biol Chem 2000, 275:31226-31232.

94. Fata JE, Leco KJ, Voura EB, Yu HY, Waterhouse P, Murphy G, Moorehead RA, Khokha R: Accelerated apoptosis in the Timp3-deficient mammary gland. J Clin Invest 2001, 108:831-841.

95. Lilla J, Stickens D, Werb Z: Metalloproteases and adipogenesis: a weighty subject. Am J Pathol 2002, 160:1551-1554.

96. Wolf K, Mazo I, Leung H, Engelke K, von Andrian UH, Deryugina $\mathrm{EI}$, Strongin AY, Brocker EB, Friedl P: Compensation mechanism in tumor cell migration: mesenchymal-amoeboid transition after blocking of pericellular proteolysis. J Cell Bio/ 2003, 160:267-277.

97. Williams JM, Daniel CW: Mammary ductal elongation: differentiation of myoepithelium and basal lamina during branching morphogenesis. Dev Biol 1983, 97:274-290.

98. Petersen OW, Lind NH, Gudjonsson T, Villadsen R, RonnovJessen L, Bissell MJ: The plasticity of human breast carcinoma cells is more than epithelial to mesenchymal conversion. Breast Cancer Res 2001, 3:213-217.

99. van 't Veer LJ, Dai H, van de Vijver MJ, He YD, Hart AA, Bernards $\mathrm{R}$, Friend $\mathrm{SH}$ : Expression profiling predicts outcome in breast cancer. Breast Cancer Res 2002, 5:57-58.

100. van de Vijver MJ, He YD, van't Veer LJ, Dai H, Hart AA, Voskuil DW, Schreiber GJ, Peterse JL, Roberts C, Marton MJ, Parrish M, Atsma D, Witteveen A, Glas A, Delahaye L, van der Velde T, Bartelink $\mathrm{H}$, Rodenhuis S, Rutgers ET, Friend SH, Bernards R: A gene-expression signature as a predictor of survival in breast cancer. N Engl J Med 2002, 347:1999-2009.

101. Wang W, Wyckoff JB, Frohlich VC, Oleynikov $Y$, Huttelmaier S, Zavadil J, Cermak L, Bottinger EP, Singer RH, White JG, Segall $\mathrm{JE}$, Condeelis JS: Single cell behavior in metastatic primary mammary tumors correlated with gene expression patterns revealed by molecular profiling. Cancer Res 2002, 62:62786288.

102. Thompson EW, Yu M, Bueno J, Jin L, Maiti SN, Palao-Marco FL, Pulyaeva H, Tamborlane JW, Tirgari R, Wapnir I, et al.: Collagen induced MMP-2 activation in human breast cancer. Breast Cancer Res Treat 1994, 31:357-370.

103. Lagace R, Grimaud JA, Schurch W, Seemayer TA: Myofibroblastic stromal reaction in carcinoma of the breast: variations of collagenous matrix and structural glycoproteins. Virchows Arch A Pathol Anat Histopathol 1985, 408:49-59. 
104. Wetzels RH, Robben HC, Leigh IM, Schaafsma HE, Vooijs GP, Ramaekers FC: Distribution patterns of type VII collagen in normal and malignant human tissues. Am J Pathol 1991, 139: 451-459

105. Barsky SH, Rao CN, Grotendorst GR, Liotta LA: Increased content of Type V Collagen in desmoplasia of human breast carcinoma. Am J Pathol 1982, 108:276-283.

106. D'Ardenne AJ, Richman PI, Horton MA, McAulay AE, Jordan S: Co-ordinate expression of the alpha- 6 integrin laminin receptor sub-unit and laminin in breast cancer. J Pathol 1991, 165: 213-220.

107. Rudolph-Owen LA, Matrisian LM: Matrix metalloproteinases in remodeling of the normal and neoplastic mammary gland. $J$ Mammary Gland Biol Neoplasia 1998, 3:177-189.

108. Zutter MM, Mazoujian G, Santoro SA: Decreased expression of integrin adhesive protein receptors in adenocarcinoma of the breast. Am J Pathol 1990, 137:863-870.

109. Zutter MM, Krigman HR, Santoro SA: Altered integrin expression in adenocarcinoma of the breast. Analysis by in situ hybridization. Am J Pathol 1993, 142:1439-1448.

110. Warner MR: Effect of various doses of estrogen to $\mathrm{BALB} / \mathrm{cCrgl}$ neonatal female mice on mammary growth and branching at 5 weeks of age. Cell Tissue Kinet 1976, 9:429438.

111. Daniel CW, Silberstein GB, Strickland P: Direct action of 17 beta-estradiol on mouse mammary ducts analyzed by sustained release implants and steroid autoradiography. Cancer Res 1987, 47:6052-6057.

112. Silberstein GB, Van Horn K, Shyamala G, Daniel CW: Essential role of endogenous estrogen in directly stimulating mammary growth demonstrated by implants containing pure antiestrogens. Endocrinology 1994, 134:84-90.

113. Atwood CS, Hovey RC, Glover JP, Chepko G, Ginsburg E, Robison WG, Vonderhaar BK: Progesterone induces sidebranching of the ductal epithelium in the mammary glands of peripubertal mice. J Endocrino/ 2000, 167:39-52.

114. Wysolmerski JJ, Philbrick WM, Dunbar ME, Lanske B, Kronenberg $H$, Broadus AE: Rescue of the parathyroid hormone-related protein knockout mouse demonstrates that parathyroid hormone-related protein is essential for mammary gland development. Development 1998, 125:1285-1294.

115. Wysolmerski JJ, McCaughern-Carucci JF, Daifotis AG, Broadus $A E$, Philbrick WM: Overexpression of parathyroid hormonerelated protein or parathyroid hormone in transgenic mice impairs branching morphogenesis during mammary gland development. Development 1995, 121:3539-3547.

116. Zhu Z, Jiang W, Thompson HJ: Effect of corticosterone administration on mammary gland development and p27 expression and their relationship to the effects of energy restriction on mammary carcinogenesis. Carcinogenesis 1998, 19:21012106.

117. Coleman S, Silberstein GB, Daniel CW: Ductal morphogenesis in the mouse mammary gland: evidence supporting a role for epidermal growth factor. Dev Biol 1988, 127:304-315.

118. Robinson SD, Silberstein GB, Roberts AB, Flanders KC, Daniel $\mathrm{CW}$ : Regulated expression and growth inhibitory effects of transforming growth factor-beta isoforms in mouse mammary gland development. Development 1991, 113:867-878.

119. Silberstein GB, Daniel CW: Reversible inhibition of mammary gland growth by transforming growth factor-beta. Science 1987, 237:291-293.

120. Ruan W, Kleinberg DL: Insulin-like growth factor I is essential for terminal end bud formation and ductal morphogenesis during mammary development. Endocrinology 1999, 140: 5075-5081.

121. Yant J, Buluwela L, Niranjan B, Gusterson B, Kamalati T: In vivo effects of hepatocyte growth factor/scatter factor on mouse mammary gland development. Exp Cell Res 1998, 241:476-481.

122. Bani G, Bigazzi M, Bani D: The effects of relaxin on the mouse mammary gland. II. The epithelium. J Endocrinol Invest 1986, 9:145-152.

123. Kenney NJ, Smith GH, Rosenberg K, Cutler ML, Dickson RB: Induction of ductal morphogenesis and lobular hyperplasia by amphiregulin in the mouse mammary gland. Cell Growth Differ 1996, 7:1769-1781.

124. Jones FE, Jerry DJ, Guarino BC, Andrews GC, Stern DF: Heregulin induces in vivo proliferation and differentiation of mammary epithelium into secretory lobuloalveoli. Cell Growth Differ 1996, 7:1031-1038.

125. Brisken C, Heineman A, Chavarria T, Elenbaas B, Tan J, Dey SK McMahon JA, McMahon AP, Weinberg RA: Essential function of Wnt-4 in mammary gland development downstream of progesterone signaling. Genes Dev 2000, 14:650-654.

126. Bradbury JM, Edwards PA, Niemeyer CC, Dale TC: Wnt-4 expression induces a pregnancy-like growth pattern in reconstituted mammary glands in virgin mice. Dev Biol 1995, 170: 553-563.

127. Mukherjee S, Louie SG, Campbell M, Esserman L, Shyamala G: Ductal growth is impeded in mammary glands of C-neu transgenic mice. Oncogene 2000, 19:5982-5987.

128. Gouon-Evans V, Rothenberg ME, Pollard JW: Postnatal mammary gland development requires macrophages and eosinophils. Development 2000, 127:2269-2282.

129. Wiesen JF, Young P, Werb Z, Cunha GR: Signaling through the stromal epidermal growth factor receptor is necessary for mammary ductal development. Development 1999, 126:335344.

130. Xie W, Paterson AJ, Chin E, Nabell LM, Kudlow JE: Targeted expression of a dominant negative epidermal growth factor receptor in the mammary gland of transgenic mice inhibits pubertal mammary duct development. Mol Endocrinol 1997, 11:1766-1781.

131. Bocchinfuso WP, Lindzey JK, Hewitt SC, Clark JA, Myers PH, Cooper R, Korach KS: Induction of mammary gland development in estrogen receptor-alpha knockout mice. Endocrinology 2000, 141:2982-2994.

132. Shyamala G, Yang X, Silberstein G, Barcellos-Hoff MH, Dale E: Transgenic mice carrying an imbalance in the native ratio of $A$ to $B$ forms of progesterone receptor exhibit developmental abnormalities in mammary glands. Proc Natl Acad Sci USA 1998, 95:696-701.

133. Lydon JP, DeMayo FJ, Funk CR, Mani SK, Hughes AR, Montgomery CA, Jr, Shyamala G, Conneely OM, O'Malley BW: Mice lacking progesterone receptor exhibit pleiotropic reproductive abnormalities. Genes Dev 1995, 9:2266-2278.

134. Brisken C, Kaur S, Chavarria TE, Binart N, Sutherland RL, Weinberg RA, Kelly PA, Ormandy CJ: Prolactin controls mammary gland development via direct and indirect mechanisms. Dev Biol 1999, 210:96-106.

135. Joseph H, Gorska AE, Sohn P, Moses HL, Serra R: Overexpression of a kinase-deficient transforming growth factor-beta type II receptor in mouse mammary stroma results in increased epithelial branching. Mol Biol Cell 1999, 10:1221. 1234

136. Seagroves TN, Krnacik S, Raught B, Gay J, Burgess-Beusse B, Darlington GJ, Rosen JM: C/EBPbeta, but not C/EBPalpha, is essential for ductal morphogenesis, lobuloalveolar proliferation, and functional differentiation in the mouse mammary gland. Genes Dev 1998, 12:1917-1928.

137. Robinson GW, Johnson PF, Hennighausen L, Sterneck E: The $\mathrm{C} / \mathrm{EBPbeta}$ transcription factor regulates epithelial cell proliferation and differentiation in the mammary gland. Genes Dev 1998, 12:1907-1916

138. Crowley MR, Head KL, Kwiatkowski DJ, Asch HL, Asch BB: The mouse mammary gland requires the actin-binding protein gelsolin for proper ductal morphogenesis. Dev Biol 2000, 225: 407-423.

139. Garcia-Gasca A, Spyropoulos DD: Differential mammary morphogenesis along the anteroposterior axis in Hoxc6 gene targeted mice. Dev Dyn 2000, 219:261-276.

140. Darribere T, Skalski M, Cousin HL, Gaultier A, Montmory C, Alfandari D: Integrins: regulators of embryogenesis. Biol Cell 2000, 92:5-25.

\section{Correspondence}

Mina J Bissell and Jimmie E Fata, Lawrence Berkeley National Laboratory, 1 Cyclotron Road, Mail Stop 83-101, Berkeley, CA 94720, USA. Tel: +1510486 4365; fax: +1 510486 5586; e-mail: mjbissell@lbl.gov; jefata@lbl.gov 